\title{
AGAMA DALAM BAYANG-BAYANG FANATISME; Sebuah upaya Mengelola Konflik Agama
}

\author{
Imam Hanafi \\ Institute for Southeast Asian Islamic Studies (ISAIS) UIN Suska Riau \\ e-mail: imam.hanafi@,uin-suska.ac.id
}

\begin{abstract}
Abstrak
Konflik atas nama agama seringkali muncul dalam realitas sosial. Kondisi ini terjadi justru diawali oleh fanatisme yang berlebihan, yang kemudian merembet pada fundamentalisme. Konflik tersebut menunjukkan bahwa nilai-nilai agama belum diamalkan dan diterapkan dalam kehidupan masyarakat, sehingga diperlukan adanya revitalisasi nilai-nilai agama. Sehingga konflik agama itu dapat diminimalisir. Oleh karena itu, setidaknya ada beberapa upaya untuk meminimaliser gejala tersebut dengan melakukan; Pertama,. Dialog Parlementer (Parliementary Dialogue). Kedua, Mediasi; Ketiga, Pendidikan Pluralisme; Keempat. Penegakan Hukum; dan Kelima, Pembinaan Etika (akhlak)
\end{abstract}

Keywords: konflik, fanatisme, agama

\section{Pendahuluan}

Manusia adalah makhluk yang selalu melakukan interaksi sosial, sehingga muncul pertentangan dan kesamaan untuk melahirkan perubahan sosial. Situasi adanya pertentangan atau ketidakserasian antara pihak yang akan dan sedang mengadakan hubungan atau kerjasama, lebih dikenal dengan istilah konflik.

Konflik sesungguhnya menjadi sebuah realitas yang tidak dapat dihindarkan, terlebih bagi masyarakat Indonesia yang memiliki keberagaman. Eksistensi konflik sangat urgen sekali dalam kerangka peningkatan kualitas kehidupan manusia. Kehidupan tidak dapat berjalan dengan tegak tanpa ada konflik, sehingga yang perlu bagi manusia adalah bagaimana cara mereka memadukan dan mencari solusi agar konflik tersebut tidak menimbulkan kehancuran (kerusakan), namun sebaliknya dapat membantu manusia mewujudkan keseimbangan dan tumbuhnya pola introspeksi diri dalam sebuah komunitas masyarakat.

Salah satu kebanggaan bangsa Indonesia bahwa bangsa ini hidup di negara yang memiliki keberagaman budaya dan agama. Negara senantiasa 
mengapresiasi keberagaman budaya dan agama (pluralisme). Meskipun untuk mewujudkan sikap toleransi, dialog lintas budaya dan agama, selalu mendapat berbagai tantangan, negara selalu mempunyai niat dan iktikad baik. Keinginan negara yang senantiasa mengedepankan toleransi, multikultural, sering bertolak belakang dengan kondisi faktual terkini, karena masih banyaknya bukti-bukti intoleransi dalam kehidupan. Intoleransi ini menimbulkan pertentangan atau yang lebih populer disebut konflik.

Nilai-nilai yang terkandung di dalam Agama berlaku dalam kehidupan berbangsa, bernegara, dan bermasyarakat. Namun sejalan dengan perkembangan zaman, muncul pengaruh negatif globalisasi. Tingkat pemahaman masyarakat terhadap nilai-nilai agama masih sebatas pada tataran teori, sementara pada prakteknya dalam kehidupan bermayarakat, berbangsa dan bernegara, nilai-nilai tersebut belum dapat diamalkan sepenuhnya oleh masyarakat.

Degradasi pemahaman masyarakat terhadap nilai-nilai toleransi, persaudaraan, kesetaraan, dan kerukunan, menimbulkan konflik horisontal. Nilai-nilai tersebut sering kali dianggap tidak berperan ketika dihadapkan pada konflik-konflik yang terjadi dalam masyarakat. Konflik yang terjadi antara lain adalah konflik antar ras atau suku di Kalimantan, antar kelompok beragama seperti pembakaran gereja atau masjid (peristiwa Ketapang, Jakarta 1998, Kupang, Januari 1999, Gereja GKI Bogor pada Desember 2012); antar jamaah atau madzhab (Ahmadiyah di Cikeusik 6 Februari 2011, Syiah di Sampang, Madura pada Desember 2011); penjarahan, tawuran, pembunuhan, dan pemerkosaan.

Berbagai konflik yang telah menimbulkan tindak kriminal tersebut, akan menimbulkan konflik sosial yang lebih besar. Konflik tersebut menunjukkan bahwa nilai-nilai agama belum diamalkan dan diterapkan dalam kehidupan masyarakat, sehingga diperlukan adanya revitalisasi nilai-nilai agama. Sehingga konflik agama itu dapat diminimalisir.

Beberapa tulisan atau riset terkait dengan upaya ini adalah Imam Subkhan (2011) berpendapat bahwa konflik dapat diminimalisir bila ada agenda ketulusan membangun dialog dan membuka prasangka di tingkat basis, Negara juga punya kewajiban menjamin hak-hak warganya. Misalnya hak untuk hidup aman tanpa ancaman dalam menjalankan kepercayaan dan agamanya, jaminan kebebasan beribadah, berpendapat dan berkumpul. Tapi melihat fakta ketidakberdayaan penegak hukum menghadapi kelompok-kelompok yang memaksakan kehendak mereka sehingga melanggar hak orang lain. Jalan yang paling mungkin adalah kembali ke praktik keseharian, yaitu wacana dan relasi kemanusiaan yang kita selami sehari-hari, yang terkadang dianggap remeh, namun sesungguhnya punya peran besar dalam membangun kelenturan sosial atau yang 
dikenal dengan istilah toleransi dan pluralisme, yang tidak dibebani oleh narasi-narasi.

Riset lainnya, dalam penelitian kuantitatif, Ibnu Syamsi (2009) menjelaskan bahwa agama mempunyai pengaruh yang cukup signifikan terhadap konflik sosial masyarakat di kelurahan Condongcatur. Penelitian yang menggunakan regresi ganda menunjukkan sumbangan efektif variabel bebas adalah $21,6 \%$, dan masing-masing sumbangan variabel bebas, yaitu agama 10,8 \% terhadap konflik sosial masyarakat, kelas sosial 2,2 \%, budaya 3,0 \%, suku 2,3\%, kepentingan $0,7 \%$ dan pribumi-non pribumi 2,6 \%. Hasil tersebut memperlihatkan bahwa faktor-faktor yang berperan dalam konflik sosial masyarakat Condongcatur: agama, budaya, pribuminonpribumi, suku, kelas sosial, dan kepentingan. Sedangkan sisanya adalah unique factor.

Penelitian Hamzah (2010) menjelaskan bahwa konflik sosial bernuansa agama di Ambon-Lease dikenal dengan konflik horizontal bernuansa vertikal. Konflik ini terjadi beberapa kali dengan melibatkan masa kedua pihak (Islam dan Kristen) dalam jumlah besar, berlangsung lama dan banyak korban. Akar-akar masalahnya teridentifikasi pada motif-motif: pemahaman agama, bias sejarah, etnis, karakter sosial dan kepentingan, mengkristal pada dua hal pokok, yaitu ekonomi dan politik. Isu Nursalim dan Yopy hanyalah desas-desus sebagai pemicu belaka. Provokator misterus-lah yang berada di tempat kejadian perkara. Pela-gandong sebagai pola penyelesaian konflik tetap eksis dan efektif namun tidak maksimal fungsinya akibat himpitan multidimensi modernitas.

Oleh karena itu, penting untuk melihat bagaimana kaitan agama dengan berbagai variasi fanatismenya, yang kemudian melahirkan konflik. Tulisan ini, akan mencoba melihat kerangka konflik dalam tataran fanatisme dalam agama, terutama Islam.

\section{Konflik dalam Bacaan}

Konflik sosial dapat diartikan dua hal: pertama, perspektif atau sudut pandang tertentu di mana konflik dianggap selalu ada dan mewarnai segenap aspek interaksi manusia dan struktur sosial; kedua, pertikaian terbuka seperti perang, revolusi, pemogokan dan gerakan perlawanan (Kuper, 2000:155). Jenis konflik umumnya berlangsung dalam konteks hubungan saling tergantung dan hubungan pertukaran yang melembaga, sehingga jenis konflik yang satu dengan yang lain selalu terdapat kemiripan, meskipun variasi juga selalu ada. Dari berbagai jenis konflik tersebut, ada tiga varian terpenting yang saling terkait, yakni pertama, karakter pihak yang berkonflik, kedua, hakekat tujuan serta ketiga, sarana yang digunakan dalam konflik itu sendiri (Kuper, 2000:155).

Lewis A. Coser (1956) berpendapat bahwa konflik dapat merupakan proses 
yang bersifat instrumental dalam pembentukan, penyatuan dan pemeliharaan struktur sosial. Konflik dapat menempatkan dan menjaga garis batas antara dua atau lebih kelompok. Konflik dengan kelompok lain dapat memperkuat kembali identitas kelompok dan melindunginya agar tidak lebur ke dalam dunia sosial sekelilingnya. Seluruh fungsi positif konflik tersebut dapat dilihat dalam ilustrasi suatu kelompok yang sedang mengalami konflik dengan kelompok lain. Konflik yang terjadi bertahun-tahun antara komunitas Syiah dan Sunni menurut Coser akan memperkuat identitas kelompok.

Coser (1956) membagi konflik menjadi dua, yaitu:

1. Konflik Realistis, berasal dari kekecewaan terhadap tuntutan-tuntutan khusus yang terjadi dalam berinteraksi dan umumnya ditujukan pada obyek yang dianggap mengecewakan. Contohnya komunitas Sunni membakar rumah dan masjid komunitas Syiah

2. Konflik Non-Realistis, konflik yang berasal dari kebutuhan untuk meredakan ketegangan dari salah satu pihak. Coser menjelaskan dalam masyarakat yang buta huruf pembalasan dendam biasanya melalui ilmu gaib seperti teluh atau santet. Coser menjelaskan bahwa ada suatu kemungkinan seseorang atau kelompok terlibat dalam konflik realistis tanpa sikap permusuhan atau agresi.

Misalnya, Komunitas Syiah akan agresif melindungi kelompoknya, tetapi setelah berada di luar desa, komunitas Syiah dan Sunni melupakan perbedaan dan berinteraksi atau berkomunikasi secara aktif.

Bila konflik berkembang dalam hubungan-hubungan yang intens, maka pemisahan (antara konflik realistis dan non-realistis) akan lebih sulit untuk dipertahankan. Coser menyatakan bahwa, semakin dekat suatu hubungan semakin besar rasa kasih sayang yang sudah tertanam, sehingga semakin besar juga kecenderungan untuk menekan ketimbang mengungkapkan rasa permusuhan. Sedang pada hubungan-hubungan sekunder, seperti misalnya dengan sesama penjual sate, rasa permusuhan dapat relatif bebas diungkapkan. Hal ini tidak selalu bisa terjadi dalam hubungan-hubungan primer dimana keterlibatan total para partisipan (komunitas Syiah dan anti Syiah) mengungkapkan perasaan bermusuhan. Hal ini berbahaya bagi hubungan tersebut. Apabila konflik tersebut benarbenar melampaui batas, maka akan menyebabkan ledakan yang membahayakan hubungan tersebut.

Coser (1967:35) menjelaskan bahwa untuk meredakan ketegangan yang terjadi dalam suatu kelompok, peningkatan konflik kelompok dapat dihubungkan dengan peningkatan interaksi dengan masyarakat secara keseluruhan. Bila konflik dalam kelompok tidak ada, berarti 
menunjukkan lemahnya integrasi

kelompok tersebut dengan masyarakat. Dalam struktur besar atau kecil, konflik ingroup merupakan indikator adanya suatu hubungan yang sehat, kuat dan stabil.

Coser (1967:37) sangat menentang para ahli sosiologi yang selalu melihat konflik hanya dalam pandangan negatif saja. Perbedaan merupakan peristiwa normal yang sebenarnya dapat memperkuat struktur sosial. Dengan demikian Coser menolak pandangan bahwa ketiadaan konflik sebagai indikator dari kekuatan dan kestabilan suatu hubungan.

\section{Konflik Bernuansa Agama}

Meskipun agama, dalam hal ini agama Islam, menjunjung tinggi prinsip-prinsip universal seperti persaudaraan, keadilan, dan tolerasi, pada prakteknya umat Islam sendiri tidak terlepas dari berbagai perselisihan, pertikaian, bahkan pertumpahan darah. Sejarah Islam bahkan mencatat konflik bernuansa agama sudah muncul dan terjadi sejak Nabi Muhammad saw. wafat. Saat itu, perselisihan mengerucut pada persoalan kepemimpinan setelah Nabi dan berujung pada munculnya faksi-faksi dalam umat Islam, seperti munculnya kelompok Sunni, Khawarij, Syi'ah, dan kelompok-kelompok lainnya (Hasan, 2012:14).

Khawarij merupakan kelompok penetang pemerintahan Ali Bin Abi Thalib dan kekuasaan Muawiyah. Nama Khawarij sendiri berasal dari kata kharaja yang berarti keluar. Nama itu dilekatakan karena mereka keluar dari kelompok Ali. Dalam persoalan Khilafah, mereka cenderung demokratis tapi dalam teologi mereka terkenal kaku (Nasution, 1986:1323). Sementara kelompok Syi'ah merupakan kelompok yang memihak kepada Ali. Pada intinya, kelompok ini bertitik tolak pada pengakuan bahwa Ali sebagai khalifah yang sah setelah Nabi wafat.

Konflik-konflik tersebut kemudian merembet ke persoalan teologi dan persoalan-persoalan lain, serta sangat berpengaruh pada relasi antar kelompok atau generasi umat Islam selanjutnya, termasuk pada munculnya kelompok Islam fundamentalis, yang kini menyebar ke berbagai penjuru dunia Muslim, termasuk Indonesia.

Menurut Azra (1993) mengutip dari Martin E. Marty, menyatakan bahwa fundamentalisme memiliki empat prinsip, yaitu:

Pertama, fundamentalisme merupakan paham perlawanan (oppositionalism) yang sering bersifat radikal terhadap ancaman yang dipandang membahayakan eksistensi agama, baik berupa modernitas, sekularisme, atau tata nilai Barat pada umumnya.

Kedua, penolakan terhadap hermeneutika. kaum fundamentalis menolak sikap kritis terhadap teks dan interpretasinya. Teks Al-Qur'an harus dipahami secara literal, karena nalar 
dipandang tidak mampu memberikan interpretasi yang tepat terhadap teks. Ketiga, penolakan terhadap pluralisme dan relativisme. Bagi kaum fundamentalis, pluralisme merupakan hasil pemahaman yang keliru terhadap teks kitab suci. Pemahaman dan sikap keagamaan yang tidak selaras dengan kaum fundamentalis dianggap sebagai bentuk relativisme keagamaan, yang terutama muncul tidak hanya dari intervensi nalar terhadap teks kitab suci, melainkan juga karena perkembangan sosial kemasyarakatan yang keluar dari kendali agama.

Keempat, penolakan terhadap perkembangan historis dan sosiologis. Kaum fundamentalis menganggap bahwa perkembangan sosiologis dan historis telah membawa manusia makin jauh dari doktrin literal kitab suci. Seharunya perkembangan masyarakat dilihat sebagai "as it should be" bukan "as it is," alias masyarakat yang harus menyesuaikan perkembangannya-jika perlu dengan kekerasan-dengan teks kitab suci, bukan sebaliknya, teks atau penafsirannya yang mengikuti perkembangan masyarakat.

Khaled Abou el-Fadl (2003:23-24) misalnya mencatat bahwa fundamentalisme keagamaan dapat ditelusuri dari doktrin kaum khawarij yang sering mengatakan bahwa la bukma illallah . Tidak jarang doktrin ini dijadikan alat legitimasi untuk mengkafirkan kelompok lain yang secara pemikiran maupun praktek berbeda. Catatan Abou Fadl ini menjadi penting karena saat ini kita dihadapkan pada munculnya kelompokkelompok umat Islam yang mudah sekali mengkafirkan orang lain. Seringkali sikap seperti ini melahirkan fanatisme keagamaan yang sempit dan berujung pada munculnya tindakan kekerasan dan konflik berkepanjangan. Apa yang terjadi dengan konflik Sampang-Madura juga tidak bisa dilepaskan dari doktrin keagamaan yang dipegang teguh para pemeluknya dan menganggap hanya kelompoknyalah yang benar, sementara yang lain sesat dan harus dibumi-hanguskan.

Fanatisme keagamaan yang berujung pada konflik tersebut, menurut Darmawan (2009) bisa disebabkan karena adanya perbedaan keyakinan dan upaya memenangkan kontrol terhadap definisi kebenaran dalam agama. Ketika agama didefinisikan berbeda dengan definisi pemeluk agama lainnya, bisa menimbulkan konflik baik yang bersifat horisontal maupun vertikal.

Di Indonesia, fanatisme keagamaan akhir-akhir ini semakin meluas dan menebar bibit-bibit perpecahan, kekerasan dan konflik. Tidak saja menyangkut perselisihan atau konflik antar agama, perselisihan dan konflik tersebut juga bisa terjadi di internal umat beragama. Berbagai contoh kekerasan antar dan inter agama sebagaimana disinggung di atas menujukkan hal tersebut sekaligus menggambarkan bahwa fanatisme keagamaan bisa terjadi pada siapa pun dan melibatkan siapa saja. Saat fanatisme keagamaan sudah menghinggapi sebuah 
kelompok beragama, tidak mustahil pertikaian, tindakan kekerasan bahkan pertupahan darah bisa terjadi.

Fanatisme keagamaan sebenarnya menjadi salah satu tantangan bagi Islam dan agama-agama lain saat ini. Bambang Sugiharto (1998:29-31) mencatat, minimal ada tiga tantangan dihadapi agama saat ini, yaitu:

Pertama, agama ditantang tampil sebagai suara moral-otentik di tengah terjadinya disorientasi nilai dan degradasi moral. Pada sisi ini, agama seringkali disibukkan dengan krisis identitas dalam dirinya sendiri, yang berakhir pada pertengkaran internal dan pada saat yang sama agama kehilangan kepekaan pada hal-hal yang bersifat substansial.

Kedua, agama ditantang untuk mampu mendobrak sikap-sikap yang mengarah pada ekslusivisme pemahaman keagamaan di tengah merebaknya krisis identitas dan pementingan kelompoknya sendiri. Agama harus menghadapi kenyataan berupa kecenderungan pluralisme, mengolahnya dalam bentuk teologi baru dan mewujudkannya dalam aksi-aksi kerjasama plural.

Ketiga, agama ditantang untuk melawan segala bentuk penindasan dan ketidakadilan yang terjadi, termasuk "ketidakadilan kognitif", yang biasanya diciptakan oleh agama sendiri.

$$
\text { Pandangan Bambang }
$$
bahwa tantangan agama ini semakin sulit dijawab karena beberapa faktor, yaitu:
Pertama, kemelut dalam tubuh masingmasing agama seringkali terproyeksi keluar. Sikap agresif berlebihan terhadap pemeluk agama lain seringkali merupakan ungkapan yang tidak bisa dihindari dari chaos dan ketegangan dalam tubuh agama itu sendiri. Kecemasan akibat tuntuan sekular yang tidak bisa dihindarkan, ketidakpastian dogmatik akibat keragaman interpretasi, serta krisis identitas akibat persaingan sosio-kultural, dan sebagainya mudah memantul ke dalam bentuk fanatisme dan kekerasan religius terhadap pemeluk agama lain.

Kedua, paham tentang kemutlakan Tuhan juga memudahkan orang untuk mengidentikan kemutlakan itu dengan kemutlakan agama yang diyakininya. Secara psikologis, sikap demikian memudahkan orang untuk melegitimasi segala tidakan kekerasannya sebagai sesuatu yang "dikehendaki oleh Tuhan".

Ketiga, terkait dengan keyakinan akan kemutlakan Tuhan, segala tindakan yang "dikehendaki Tuhan" dianggap akan diganjar oleh Tuhan. Pada konteks ini, tindakan kekerasan terhadap pemeluk agama lain justeru dinilai merupakan bagian dari keutamaan moral.

Keempat, naik-daunnya posisi agama dalam konstelasi peradaban saat ini membuat agama rawan dituggangi kepentingan-kepentingan politik, ekonomi, dan kultural pribadi atau kelompok-kelompok tertentu. Jika ini terjadi, integritas agama terancam hancur. 
Alih-alih menjadi solusi bagi kemelut modernitas, agama justeru akan semakin dirasakan sebagai penyakit yang berbahaya. Alih-alih menjadi berkah, agama tampil justeru sebagai kutukan.

Persoalan agama ditunggangi memang merupakan masalah yang banyak menyita perhatian saat ini. Banyak yang meyakini bahwa berbagai tindakan kekerasan dan konflik yang terjadi dan melibatkan umat beragama sebenarnya tidak mencerminkan ajaran agama itu sendiri, melainkan lebih bermakna politis, ekonomis, atau sosiokultural. Hal ini didasarkan pada alasan bahwa berbagai tindakan kekerasan dan konflik tersebut berpunggungan atau bertentangan dengan prinsip-prinsip universal yang diyakini masing-masing agama. Dalam ajaran Islam misalnya diyakini adanya prinsip-prinsip universal seperti musyawarah (asy-syura), kesetaraan (al-musawwa) dan persaudaraan (al-ikha), keadilan (al-'adalab), kebebasan (alburriyyah), keterpercayaan (al-amanab), perdamaian (as-salam), prinsip toleransi (attasamub). Karena itu, lebih tepat jika kekerasan dan konflik yang terjadi tidak disebut sebagai kekerasan dan konflik menurut agama melainkan kekerasan dan konflik atas nama agama.

Perselisihan dan konflik Sunni-Syi'ah yang terjadi jauh sebelum Indonesia merdeka juga terjadi karena persoalan politik yang berkembang menjadi persoalan akidah, tarekat, filsafat dan tasawuf. Motif politik menjadi dorongan kuat dalam memperoleh kepercayaan, pengaruh, dan kekuasaan, baik yang berasal dari pemerintah maupun dari masyarakat. Hubungan Sunni dan Syi'ah menjadi hubungan antagonistik, berhadaphadapan, dan melahirkan perang saudara. Permusuhan Sunni-Syi'ah terjadi di Kerajaan Peureulak dan Kerajaan Samudera Islam Pasai. Arya Bakooy (Maharaja Ahmad Permala) diangkat sebagai Perdana Menteri di Kerajaan Saumdera Islam Pasai (1400-1428 M). Perdana Menteri yang berasal dari aliran Syi'ah ekstrim ini menyuruh membunuh 40 ulama Sunni dan meletuslah perang saudara. Kelompok Syi'ah dipimpin sang Perdana Menteri, sedangkan kelompok Sunni dipimpin oleh Malik Musthofa yang dibantu oleh Sultan Mahmud II, Alaidin Johan Syah.

Saat ini perselisihan atau konflik atas nama agama juga bisa dipicu oleh faktor sosial-budaya. Perselisihan dan konflik yang terjadi dilatarbelakangi oleh adanya pemikiran dan praktek keberagamaan yang berbeda. Kelompok Islam yang fanatik mengecam dan menentang berbagai pemikiran dan tradisi kelompok lain yang tidak sesuai dengan pemikiran dan tradisinya. Atas nama "Islam autentik" atau "Islam asli", mereka mengutuk dan memusuhi umat Islam lain yang dianggapnya menyimpang dari ajaran Islam yang sebenarnya. Hal ini tergambar jelas dalam ungkapan yang sering terdengar akhir-akhir ini, dimana seseorang atau sekelompok umat Islam menyebut kelompok Islam lainnya sebagai 
penganut bid'ah, aliran sesat, dan berpaham Sipilis (sekulerisme, pluralisme, dan liberalisme). Klaim-klaim seperti ini tidak hanya berada dalam dataran wacana. Dalam prakteknya sering ditemukan sekelompok umat Islam melakukan tindakan kekerasan terhadap kelompok lain yang tidak sealiran.

Faktor-faktor Penyebab Konflik Antar Umat Beragama

\section{Klaim Kebenaran (Truth Claim)}

Kecenderungan umat beragama berupaya membenarkan ajaran agamnya masingmasing, meskipun ada yang tidak paham terhadap nilai-nilai luhur yang terkandung dalam agama yang dia bela tersebut. Namun semangat yang menggelora kadang kala telah merendahkan orang lain yang tidak sepaham dengannya meskipun berasal dari satu agama. Harus diakui keyakinan tentang yang benar itu didasarkan pada Tuhan sebagai satusatunya sumber kebenaran. Pluralitas manusia menyebabkan wajah kebenaran itu tampil beda ketika akan dimaknakan. Sebab perbedaan ini tidak dapat dilepaskan begitu saja dari berbagai referensi dan latar belakang orang yang meyakininya. Mereka mengklaim telah memahami, memiliki, bahkan menjalankan secara murni terhadap nilai-nilai suci itu.

Keyakinan tersebut akan berubah menjadi suatu pemaksaan konsepkonsep gerakannya kepada orang lain yang berbeda keyakinan dan sepemahaman dengan mereka. Armahedi Mazhar (2014) menyebutkan bahwa absolutisme, eksklusivisme, fanatisme, ekstremisme dan agresivisme adalah penyakit-penyakit yang biasanya menghinggapi aktivis gerakan keagamaan. Absolutisme adalah kesombongan intelektual, eksklusivisme adalah kesombongan sosial, fanatisme adalah kesombongan emosional, ekstremisme adalah berlebih-lebihan dalam bersikap dan agresivisme adalah berlebih-lebihan dalam melakukan tindakan fisik.

Dalam ajaran atau doktrin agama, terdapat seruan untuk menuju keselamatan yang dibarengi dengan kewajiban mengajak orang lain menuju keselamatan tersebut. Kegiatan ini biasa disebut dengan istilah "dakiyah".

Dakiyah merupakan upaya mensosialisasikan (mengajak, merayu) ajaran agama. Bahkan tidak menutup kemungkinan, masing-masing agama akan menjastifikasi bahwa agamalah yang paling benar. Jika kepentingan ini lebih diutamakan, masing-masing agama akan berhadapan dalam menegakkan hak kebenarannya. Ini akan memunculkan sentimen agama, sehingga benturan pun sulit dihindari. Fenomena yang seperti inilah yang dapat merusak kerukunan umat beragama serta berpotensi melahirkan konflik agama. 
2. Doktin Jihad Pasca bom Bali I banyak orang tersentak ketika Imam Samudra, tersangka utama bom Bali, mengeluarkan pernyataan mencengangkan di hadapan wartawan. "Ini adalah perjuangan suci (jibad), bukan perjuangan bina. Insya Allah, Allabu akbar!"

Tentu saja, pernyataan Imam Samudra tersebut menyisakan banyak pertanyaan dalam pikiran semua orang tentang konsep jihad dalam Islam. Dalam agama memang dikenal konsep jihad, namun bukan jihad sebagaimana yang dipahami oleh Imam Samudra seperti di atas, yaitu membunuh orang tanpa berdosa karena disebabkan oleh doktrin-doktrin tertentu. Ajaran agama memang doktrin, tetapi agama memberikan kebebasan kepada pemeluknya untuk menafsirkan teksteks kitab suci dalam agama.

Belakangan yang terjadi di negara Indonesia banyak pihak melegitimasi kekerasan atas nama Tuhan, padahal kekerasa dari perspektif manapun tidak dibenarkan terlebih lagi dari sudut pandang agama, terutama Islam, yang mendeklarasikan kedamaian sebagai inti ajarannya. Jihad dalam Islam dimulai ketika Nabi saw hijrah dari Mekkah ke Madinah.

Dalam hal ini, harus dimengerti bahwa Madinah adalah semacam "negara muslim" yang harus mempertahankan eksistensinya melawan orang-orang Arab dari klan Quraisy ketika itu. Dari sinilah ajaran Islam tentang jihad itu berkembang. Sebenarnya tafsiran paling mutakhir tentang jihad selalu bersifat defensif.

Dengan demikian, pada periode modern, pengertian jihad sama sekali tak bermakna ofensif. Konteks jihad pada fase Madinah saat itu Nabi saw harus mempertahankan eksistensi komunitas muslim yang dirongrong oleh suku Quraisy yang berdomisili di Mekkah, beberapa suku Yahudi di Madinah, dan beberapa suku Badui. Jadi, saat itu memang ada doktrin Islam yang mengajarkan Nabi saw mempertahankan diri dari serangan musuh.

Namun demikian, doktrin tersebut juga bermakna agak ofensif. Misalnya, kasus penyerangan atau penaklukan kota Mekkah (fath al-Makkah). Tanpa menyerang Mekkah ketika itu, hampir mustahil Nabi saw bisa menguasai jazirah Arab secara keseluruhan.

Jihad pada era modern sekarang dapat dimaknai dari berbagai perspektif, karena jihad sekalipun identik dengan peperangan fisik, sekarang harus dibalik ke jihad sosial yaitu bagaimana memerangi kemiskinan dan kebodohan umat, karena banyak sekali kasus yang menimpa umat Islam disebabkan oleh ketidak mampuan umat Islam memerangi kemiskinan dan kebodohan 
sehingga dalam banyak bidang umat Islam mengalami diskriminasi akibat kemiskinan dan kebodohan tersebut. Semangat perubahan tidak mungkin terwujud kecuali dengan adanya jihad. (Tasmara, 2002:39).

Doktrin inilah seharusnya yang perlu ditanamkan kepada generasi muda, agar pemuda Islam mampu mensejajarkan diri dengan pemudapemuda dari agama lain yang sekarang jauh lebih maju. Saat ini banyak orang elergi mendengarkan kata-kata jihad, padahal tanpa semangat jihad niscaya seorang muslim tidak mempunyai nilai apapun, harga diri seorang muslim tidak lengkap tanpa ruh jihad. Jihad di sini pada intinya adalah bersungguhsungguh mengerahkan segala kemampuan untuk menegakkan kejayaan dan martabat umat Islam

\section{Upaya mereduksi Konflik}

Akar permasalahan dan kronologis terjadinya konflik, biasanya diawali dengan tiadanya akhlak, dan perilaku masyarakat sangat jauh dari nilai-nilai agama. Fungsi dan peran agama seharusnya dijadikan pedoman dalam berfikir dan bertindak, realitasnya nilai-nilai agama bukan lagi menjadi arah dalam kehidupan bermasyarakat. Fakta yang berkaitan dengan perilaku bangsa yang tidak mencerminkan nilai-nilai agama, adalah penyimpangan terhadap nilai-nilai agama.

Oleh karena itu, diantara upaya untuk mereduksi konflik dalam hubungan agama adalah sebagai berikut, Pertama. Musyawarah atau dialog. Dialog, baik di dalam hubungan kekerabatan dan ketetanggaan maupun yang berkaitan dengan persoalan lain. Adanya dialog yang intensif dan terbuka antara keyakinan pada level akar rumput. Para Ulama (MUI), pemuka adat, tokoh masyarakat dari pihak berbagai pemahaman seharusnya menghilangkan kepentingan politisnya dan kepentingan organisasinya untuk tujuan yang lebih mulia, yaitu perdamaian. Dalam dialog tidak perlu menonjolkan sisi negatif, justru yang paling penting adalah menonjolkan sisi positif dari setiap faham. Perihal jalan menuju dialog ini sebenarnya pernah dirintis oleh $\mathrm{KH}$ Abdurrahman Wahid.

Model dialog keagamaan yang ditawarkan antara lain seperti yang dikemukakan oleh Kimball (Faisal Ismail, 1999: 9-11); Pertama,. Dialog Parlementer (Parliementary Dialogue). Dialog ini dilakukan dengan melibatkan tokoh-tokoh umat beragama di tingkat dunia. Misalnya dengan telah dibentuk dan dilakukannya World's Parliement of Religions dan Confrence on Religions and Peace, dan The World Congress of Faiths. Tujuannya adalah mengembangkan kerjasama dan perdamaian di antara umat beragama di dunia.

Kedua, Dialog Kelembagaan (Institutional Dialogue). Dialog ini dilakukan dengan melibatkan organisasi-organisasi keagamaan. Tujuannya mendiskusikan dan memecahkan persoalan keumatan dan 
mengembangkan komunikasi di antara organisasi keagamaan (PGI, Walubi, KWI, Parisadha Hindu Dharma, MUI, dan lainlain).

Ketiga, Dialog Teologi (Theological Dialogue). Tujuan dilakukannya dialog model ini adalah untuk membahas persoalan-persoalan teologis-filosofis. Dialog ini dimaksudkan untuk memberikan pemahaman mengenai konsep teologis masing masing agama. Berusaha membangun pemahaman sesuai dengan yang dikehendaki oleh suatu agama tertentu dan menghindari pemahaman yang bersifat subjektif.

Keempat, Dialog dalam Masyarakat (Dialogue in Community). Dilaog ini dilakukan dengan cara atau dalam bentuk kerjasama dari komunitas agama yang plural dalam menggarap dan menyelesaikan masalah-masalah praktis dalam kehidupan sehari hari.

Kelima, Dialog Kerohanian (Spiritual Dialogue). Dialog model ini dilakukan dengan tujuan mengembangkan dan memperdalam kehidupan spiritual di antara berbagai agama.

Model-model dialog di atas bisa dipilih sebagai sarana yang bisa digunakan untuk membangun keharmonisan hidup di antara umat beragama. Melalui dialog itu akan berkembangn model pemahaman keagamaan yang tidak semata menegaskan perbedaan, melainkan juga mencari titik temu atau persamaan-persamaan yang ada di antara agama-gama itu. Dialog antar iman ini diharapkan akan mengantarkan umat beragama dari paradigma 'kesalehan ritual' dan 'kesalehan individual' kepada bentuk 'kesalehan sosial'.

Kedua, Mediasi. Bila melalui jalur musyawarah tidak berhasil, maka dapat ditempuh jalur mediasi atau pihak ketiga sebagai mediator/penengah. Pihak netral sebagai mediator yang paling berkompeten adalah pemerintah. Pemerintahpun diharapkan menghilangkan kepentingan ekonomi dan politisnya dan mengambil posisi netral, tidak berpihak pada yang satu dan pihak yang lainnya dalam mempertimbangkan keputusan akhir. Keputusan akhir tetap ada di tangan kedua pihak.

Ketiga, Pendidikan Pluralisme. Pendidikan pluralisme yaitu suatu pendidikan yang mengandaikan kita untuk membuka visi pada cakrawala yang semakin luas, mampu melintas batas kelompok etnis atau tradisi budaya dan agama kita. Para Ulama, Kyai, Ustad yang ada di pesantren mengajarkan umat dan santri-santrinya bahwa Indonesia adalah negara Bhineka Tunggal Ika. Harapannya adalah bahwa kita mampu melihat "kemanusiaan" sebagai sebuah keluarga yang memiliki baik perbedaan maupun kesamaan cita-cita. Inilah pendidikan akan nilai-nilai dasar kemanusiaan untuk perdamaian, kemerdekaan, dan solidaritas. Reformasi pendidikan yang berbasis multikultur atau keanekaragaman, memungkinkan masyarakat dapat bersikap toleran. Masyarakat dapat 'membongkar' 
teologi agama masing-masing yang selama ini cenderung ditampilkan secara eklusif dan dogmatis. Sebuah teologi yang biasanya hanya mengklaim bahwa hanya agamanya yang bisa membangun kesejahteraan duniawi dan mengantar manusia dalam surga Tuhan.

Keempat. Penegakan Hukum. Penegakan hukum terhadap pelaku kekerasan di manapun, harus mendapat perhatian serius dari pemerintah. Penegakan hukum juga merupakan elemen penting dalam penyelesaian konflik. Langkah ini penting agar siapa pun di negeri ini tidak mudah menggunakan kekerasan dalam penyelesaian masalah. Kekerasan yang berulang-ulang dilakukan oleh sebuah kelompok karena tidak ada sanksi hukum yang tegas dan berat terhadap pelaku kekerasan, akan selalu terulang di masa yang akan datang. Mestinya, mereka yang melakukan kekerasan dengan mengatasnamakan keyakinan dan agama mendapat ganjaran yang setimpal karena mereka telah melakukan dua pelanggaran sekaligus yaitu norma hukum dan norma agama yang sama sekali tidak membenarkan kekerasan. Pemerintah tidak boleh lagi melakukan pembiaran terhadap kelompok yang menebarkan kebencian dan kekerasan di negeri ini karena sebagaimana diamanatkan dalam pembukaan UUD 1945 bahwa negara berkewajiban untuk melindungi setiap warga negara, apa pun agama, suku, ras, dan alirannya. Satu nusa, satu bangsa, dan satu bahasa yaitu Indonesia.

Kelima, Pembinaan Etika (akhlak). Sejarah menunjukkan bahwa implementasi dan konsistensi Agama mengalami pasang-surut yang disebabkan oleh faktor internal, eksternal, dan komitmen pimpinan nasional. Oleh karenanya, pimpinan nasional sudah seharusnya memegang teguh nilai-nilai Agama dalam penyelenggaraan negara. Para ulama dan tokoh pemuda, tokoh masyarakat, pejabat pemerintahan, pejabat negara, baik yang ada di pusat dan daerah memberi contoh/teladan dan perbuatan yang nyata. Etika (akhlak) dalam mewujudkan cita-cita tersebut harus selalu diperhatikan dengan penuh antisipasi, karena dengan bekal ini pergolakan atau konflik apapun akan dapat dikendalikan dengan baik, dan dengan sendirinya akan dapat medatangkan kondisi yang lebih baik (maslahah).

\section{Penutup}

Indonesia dikenal sebagai negara majemuk, baik secara suku (etnis), kebudayaan maupun agama. Kemajemukan ini haruslah disikapi sebagai khazanah kekayaan bangsa dan bukan merupakan suatu kekurangan yang harus dihapuskan. Dengan pluralitas yang dipikul oleh bangsa ini, mengharuskan masyarakatnya mempunyai sikap yang toleran; lapang dada, bertolak angsur dan tepa selera, agar kehidupan dapat berjalan dengan baik. 
Kemajemukan adalah sebuah fenomena yang tidak mungkin dihindari. Kita hidup dalam kemajemukan dan merupakan bagian dari proses kemajemukan, aktif maupun pasif. Ia menyusup dan menyangkut dalam setiap dan seluruh ruang kehidupan kita, tak terkecuali juga dalam hal kepercayaan. Kita menghadapi kenyataan adanya berbagai agama dengan umatnya masingmasing. Dalam menghadapi kemajemukan seperti ini, tentu saja kita tidak mungkin mengambil sikap anti pluralisme. Kita harus belajar toleran terhadap kemajemukan. Kita dituntut untuk hidup di atas dasar dan semangat pluralisme.

Bangsa Indonesia sering menyebut dirinya sebagai bangsa yang religius, artinya semua orang yang tinggal di Indonesia harus menganut salah satu agama yang ada (diakui) di Indonesia. Hal ini menyiratkan bahwa orang yang tidak menganut salah satu agama (atheis) tidak mendapatkan tempat di Indonesia. Paling tidak ada lima agama besar yang diakui di Indonesia, dan Islam merupakan agama mayoritas yang dianut oleh bangsa ini, di samping agama-agama lainnya. Pemeluk barbagai agama ini hidup secara berdampingan dan menyebar di seluruh Indonesia, meskipun agama tertentu terdapat penganut yang banyak di daerah tertentu.

Keanekaragaman (pluralitas) agama yang hidup di Indonesia, termasuk di dalamnya keanekaragaman paham keagamaan yang ada di dalam tubuh intern umat beragama adalah merupakan kenyataan historis yang tidak dapat disangkal oleh siapa pun.

Proses munculnya pluralitas agama di Indonesia dapat diamati secara empiris historis. Secara kronologis dapat disebutkan bahwa dalam wilayah kepulauan nusantara, hanya agama Hindu dan Budha yang dahulu dipeluk oleh masyarakat, terutama di Jawa. Kenyataan demikian tidak menapikan tumbuh dan berkembangnya budaya animisme dan dinamisme, baik di Jawa maupun di luar Jawa ketika penyebaran agama Islam lewat jalur perdagangan sampai kepulauan nusantara, maka proses perubahan pemelukan (conversi) agama secara bertahap berlangsung. Proses penyebaran dan pemelukan agama Islam di kepulauan nusantara yang berlangsung secara massif dan dengan jalan damai tersebut dicatat oleh Marshall Hodgson sebagai prestasi sejarah dan budaya yang amat mengagumkan. Dengan memperhatikan kondisi objektif masyarakat Indonesia yang begitu majemuk keberagamannya, maka studi agama (religious studies) terasa sangat urgen dan mendesak untuk dikembangkan. Dengan melakukan berbagai kajian - yang menggunakan pendekatan multidispliner, interdispliner dan pendekatan yang historis-kritis diharapkan akan terwujud toleransi antar umat beragama. Jika sikap toleransi tidak bisa ditumbuhkan dengan baik, maka kemungkinan terjadi berbagai konflik yang bernuansa agama - atau agama dijadikan 
alat oleh kelompok tertentu - akan mudah terjadi. Keadaan seperti ini tentu saja merugikan semua kelompok dan membuat kondisi sosial negara ini menjadi buruk. Kerukunan umat beragama yang selama ini sudah terwujud - meskipun belakangan ini terjadi beberapa konflik dan pertikaian yang mengatasnamakan agama hendaknya tetap dipertahankan. Karena kemajemukan merupakan kenyataan historis yang tidak mungkin di pungkiri. Oleh karena itu, setiap kelompok keagamaan haruslah bersikap arif dalam menyikapi keadaan ini, jangan sampai kemajemukan tersebut menjadi bencana bagi bangsa ini.

Perbedaan konsepsi diantara agamaagama yang ada adalah sebuah realitas,yang tidak dapat di mungkiri oleh siapapun. Perbedaan bahkan benturan konsepsi itu terjadi pada hampir semua aspek agama, baik di bidang konsepsi tentang Tuhan maupun konsepsi pengaturan kehidupan. Hal ini dalam prakteknya, cukup sering memicu konflik fisik antara umat berbeda agama.

Konflik Maluku, Poso, di tambah sejumlah kasus terpisah di berbagai tempat di mana kaum Muslim terlibat konflik secara langsung dengan umat Kristen adalah sejumlah contoh konflik yangsedikit banyak-dipicu oleh perbedaan konsep di antara kedua agama ini. Perang Salib (1096-1271) antara umat Kristen Eropa dan Islam, pembantaian umat Islam di Granada oleh Ratu Isabilla ketika mengusur dinasti Islam terakhir di
Spanyol, adalah konflik antara Islam dan Kristen yang terbesar sepanjang sejarah. Catatan ini, mungkin akan bertambah panjang, jika intervensi Barat (Amerika dan sekutu-sekutunya) di dunia Islam dilampirkan pula di sini.

Pandangan strereotip satu kelompok terhadap kelompok lainnya, biasanya menjadi satu hal yang muncul bersamaan dengan terdengarnya gendering permusuhan, yang diikuti oleh upaya saling serang, saling membunuh, membakar rumah-rumah ibadah seteru masing-masing dan sebagainya. Umat Islam dipandang sebagai umat yang radikal, tidak toleran, dan sangat subjektif dalam memandang kebenaran yang boleh jadi terdapat pada umat. Sebagaian kalangan berpendapat bahwa perbedaan konsep keagamaanlah yang menjadi sumber konflik utama antara umat manusia.Tidak dapat di pungkiri bahwa sejumlah teks keagamaan memang mengatur masalah kekerasan dan peperangan.Dalam Islam juga di kenal konsep jihad yang dalam sejumlah hal berarti peperangan (qital) maka sebagian penganat melihat, agama adalah sumber konflik, atau setidaknya memberikan legitimasi terhadap berbagai konflik sosial. Ferguson mencatat "Every major religious tradition includes its justification for fiolence". Sebagaian lain menyimpulkan bahwa agama-agama memberikan ajaran dan contoh-contoh yang meligitimasi pembunuhan. Dalam tradisi Islam dan agama lain, di antaranya Kristen dan 
Yahudi kata mereka, Tuhan membunuh masyarakat, dan memerintahkan masyarakat untuk melakukan hal yang sama.

Hubungan erat antara masyarakat dan Nilai-nilai Agama bukan berarti Agama yang harus menyesuaikan masyarakatnya. Tetapi perilaku masyarakat sebagai tolak ukur terhadap nilai-nilai Agama. Kemajemukan dalam masyarakat sering menimbulkan gesekan-gesekan terjadinya konflik. Konflik-konflik yang terjadi dalam masyarakat walaupun berbau agama dan etnis sering dipengaruhi oleh faktorfaktor diluar agama sebagai ras, budaya, suku, sosial, ekonomi, dan politik. Dalam hal ini, nilai-nilai Agama tidak terlalu berperan mengatasi konflik karena dikesampingkan oleh ego dan identitas kelompok.

Strategi merevitalisasi nilai-nilai Agama untuk mereduksi konflik sosial di Indonesia khususnya di Sampang, Madura, antara lain melalui: musyawarah atau dialog, mediasi, pendidikan pluralisme, penegakan hukum dan pembinaan akhlak atau etika.

Dalam konteks masyarakat multikultural, aturan perundang-undangan harus mampu menumbuhkan kemampuan setiap individu dan kelompok masyarakat untuk memiliki kapasitas penting untuk hidup bersama, yaitu kesadaran akan jati diri dan sadar akan kepentingannya, kesadaran bertindak publik yang berlandas pada kemampuan untuk menyadari dan menerima kepentingan orang lain dan kelompok lain setara dengan kepentingannya, memiliki keterampilan untuk menjadi juru bicara yang fasih dan elegan bagi kepentingan diri dan kelompoknya, menjadi pendengar yang peka terhadap kepentingan orang dan kelompok lain, serta mampu memberikan solusi-solusi kontributif dengan kerangka besar mosaik kebersamaan. 


\section{DAFTAR PUSTAKA}

Abdullah, Amin, Studi Agama: Normativitas atan Historisitas, Yogyakarta: Pustaka Pelajar, 1999.

Abdullah, Taufik (Ed). Agama dan Perubahan Sosial. Jakarta: Rajawali, 1983.

Abdurrahman, Madura dalam Selayang Pandang, Sumenep: Adikarya, 1971.

Abegebriel, A. Maftuh, dkk., Negara Tuban: The Thematic Encyclopedia, Jakarta:SR-INS Publishing, 2004.

Abidin, Zainal. Filsafat Manusia Memahami Manusia Melalui Filsafat. Bandung:Remaja Rosdakarya, 2000.

Achmad, Nur, Pluralitas Agama, Kerukunan Dalam Keragaman, Jakarta: Kompas, 2001.

Asy'arie, Musa dkk., Agama, Kebudayaan dan Pembangunan Menyongsong EraIndustrialisasi, Yogyakarta: IAIN Sunan Kalijaga Press. 1988.

Azra, Azyumardi, Jaringan Ulama: Timur Tengah dan Kepulauan Nusantara Abad XVII dan XVIII: Melacak. Akar-Akar Pembaruan Pemikiran Islam di Indonesia, cet. ke-1, Bandung: Mizan, 1994.

Bakhtiar, Amsal. Filsafat Ilmu. Jakrta: Rajagrafindo Persada, 2007.

Berlin, Isaiah. Karl Marx - Riwayat Sang Pemikir Revolusioner. (Terj. Eri Setiyawan Alkhatab dan Silvester G. Sukur). Yogyakarta: PanjiPustaka, 2007.

Colleman, James S. Dasar-Dasar Teori Sosial, (Terj. Imam Muttaqien, Derta Sri Widowtie dan Siwi
Purwandari). Bandung: Nusa Media, 2008.

Coser, Lewis, Continuities in the Study of Social Conflict, New York: Free Press, 1967.

------, The Function of Social Conflict, New York: Free Press, 1956.

Coulson, Noel J., Konflik dalam Yurisprudensi Islam, alih bahasa oleh Fuad, cet. ke-1, Yogyakarta: Navila, 2001.

Crapps, Robert W. Dialog Psikologi dan Agama (Terj. A.M. Hardjana). Yogyakarta: Kanisius 1993.

Dahrendorf, Ralf. Konflik dan Konflik Dalam Masyarakat Industri, Sebuah Analisa Konfik. Jakarta: Rajawali, 1986.

Data Sensus BPS tahun 2010

Departemen Agama RI. Al-Qur'an dan Terjemahannya. Jakarta: Intermassa, 1993.

Dermawan, Andy, Dialektika Islam dan Multikulturalisme di Indonesia: Ikbtiar Mengurai Akar Konflik, Yogyakarta: Kurnia Kalam Semesta, 2009.

Enginer, Asghar Ali. Liberalisasi Teologi Islam, Membangun Teologi Damai Dalam Islam (Terj. Rizqon Khamami). Yogyakarta: Alenia, 2004.

Fadl, Khaled M. Abou El-, Speaking in God's Name: Law Authority, and Women, Oxford: Oneworld, 2003.

Giddens, Anthony. Perdebatan Klasik dan Kontemporer Mngenai Kelompok, Kekuasaan dan Konflik. Jakarta: Rajawali, 1987.

Hadikusuma, Hilman, Pengantar Ilmu Hukum Adat Indonesia, Bandung: Mandar Maju, 1992. 
Harskamp, Anton van (Ed). Conflicts in Social Science ( London: Routledge, 1996, (Terj.) Bern. Hidayat, Konflik-Konflik Dalam Ilmu Sosial. Yogyakarta: Kanisius, 2005.

Hasan, Noorhaidi, Islam Politik di Dunia Kontemporer: Konsep Geneaologi, dan Teori, Yogyakarta: Suka Press, 2012.

Hendropuspito, O.C., D. Sosiologi Agama. Yogyakarta: Kanisus, 1983.

Hidayat, Komaruddin, Psikologi Agama: Menjadikan Hidup Lebih Ramah dan Santun, cet. ke-2, Jakarta: Hikmah, 2010.

Huda, Miftahul, Filsafat Hukum Islam, Yogyakarta: Sukses Grafia, 2006.

Jonge, Huub de (ed.), Agama, Kebudayaan, dan Ekonomi: Studi-Studi Indisipliner tentang Masyarakat Madura, Jakarta: Rajawali Press, 1989.

Kontras Surabaya, Laporan Investigasi dan Pemantauan Kasus Syi'ah Sampang, Tahun 2012.

Kuntowijoyo, Perubahan Sosial dalam Masyarakat Agraris: Madura 18501940, Yogyakarta: Matabangsa, 2002.

Maarif, Ahmad Syafii. Islam dan Masalah Kenegaraan, Studi Tentang Percaturan Dalam Konstituante. Jakarta: LP3ES, 1987.

Madjid, Nurcholish. Islam Doktrin dan Peradaban, Sebuab Telaah Kritis tentang Masalab Keimanan, Kemanusiaan dan Kemodernan. Jakarta: Yayasan Wakaf Paramadina, 1992.

Mahrudin, "Konflik Kebijakan Pertambangan Antara Pemerintah dan Masyarakat di Kabupaten Buton”, Jurnal Studi
Pemerintahan, Volume 1 Nomor 1 Agustus 2010, hal 187-204.

Mash'ud, Mustain, "Dampak Konflik Lingkungan Hidup: Perspektif Sosial, Budaya dan Politik," Jurnal Sosial-Politika, Vol. 15, No. 2, Desember 2008, hal 195-214.

Minhaji, Akh., Sejarah Sosial dalam Studi Islam: Teori Metodologi, dan Implementasi, cet. ke-1, Yogyakarta: Suka Press, 2010.

Mudzhar, M. Atho, Pendekatan Studi Islam dalam Teori dan Praktek, cet. ke- 4, Yogyakarta: Pustaka Pelajar, 2002.

Nasution, Harun, Teologi Islam: AliranAliran Sejarah Analisa Perbandingan, cet. ke-5, Jakarta: UI-Press, 1986.

Nurhajarini, Dwi Ratna dkk., Kerusuban Sosial di Madura (Kasus Waduk Nipab dan Ladang Garam), Yogyakarta: Kementrian Kebudayaan dan Pariwisata Deputi Bidang Pelestarian dan Pengembangan Kebudayaan Balai Sejarah dan Nilai Tradisional, 2005.

O'dea, Thomas F. Sosiologi Agama. Jakarta: Rajawali Pers, 1987.

Poloma, Margaret M. Sosiologi Kontemporer (Terj. Yasogama). Jakarta: RajaGrafindo Persada, 2007.

Pruitt, Dean G. dan Rubin Jeffrey Z. Teori Konflike Sosial (Terj. Helly P. Soetjipto dan Sri Mulyantini Soetjipto), Yogyakarta: Pustaka Pelajar, 2004.

Purwantono, Bambang, "Kekerasan dan Kriminalitas pada masa Transisi," makalah pada The 1st International Conferrence on Urban History, Surabaya 23-25 Agustus 2004. 
Qomar, Mujamil, Fajar Baru Islam Indonesia? (Kajian Komprehensif atas Arab Sejarah dan Dinamika Intelektual Islam Nusantara, cet. ke1, Bandung: Mizan, 2012.

Qaradhawi, Yusuf Al-, Islam Abad 21, Reflekesi Abad 20 dan Agenda Masa Depan, Terj. Samson rahman, Jakarta: Pustaka Al-Kautsar, 2001

Rahman, Asymuni A. Qaidah-Qaidah Figh, Cet. Ke-1, Jakarta: Bulan Bintang, 1997.

Rahman, Fazlur, Islam, Chicago: The University of Chicago Press, 1970.

, Islam dan Modernitas, Tentang Transformasi Intelektual, alih bahasa oleh Ahsin Mohammad, Bandung: Pustaka, 1985.

Robertson, Roland, ed. Agama : Dalam Analisa dan Intepretasi Sosiologis (Terj. Achmad Fedyani Saifuddin). Jakarta: Rajawali, 1988.

Rozaki, Abdul, Menabur Kharisma Menuai Kuasa: Kiprah Kiai dan Blater Sebagai Rezim Kembar di Madura, Yogyakarta: Pustaka Marwa, 2004.

Scharf, Betty R. Sosiologi Agama (Terj. Machnun Husein). Jakarta: Prenada Media, 2004.

Semendawai, AH., dkk., Laporan Tim Temuan dan Rekomendasi (TTR) tentang Penyerangan terhadap Penganut Syi'ab di Sampang Madura, Tahun 2013.

Semiawan, Conny R. dkk. Dimensi Kreatif Dalam Filsafat Ilmu. Bandung: Remaja Rosdakarya, 1988.

Shihab, Quraish (et.al.), Atas Nama Agama Wacana Agama dalam Dialog "Bebas" Konflik), Bandung: Pustaka Hidayah, 1998.
Soekanto, Soerjono. Sosiologi Suatu Pengantar. Jakarta: RajaGrafindo Persada,1996.

Beberapa Teori Sosiologi Tentang Struktur Masyarakat. Jakarta: Rajawali, 1984.

Teori Sosiologi Tentang Perubahan Sosial. Jakarta: Rajawali, 1986.

Subkhan, Imam, Hiruk Pikuk Wacana Pluralisme di Yogya, Cetakan ke-5, Yogyakarta: Kanisius, 2011.

Sumartana, Pluralisme, Konflik, dan Pendidikan Agama di Indonesia, Yogyakarta: Pustaka Pelajar, 2001.

Susan, Novri, Sosiologi Konflik dan Isu-Isu Konflik Kontemporer, Jakarta: Prenada Media Jakarta, 2009.

Susanto, Astrid S., Pengantar Sosiologi dan Perubahan Sosial, Jakarta: Bina Cipta, 1983.

Suseno, Frans Magnez, "Pendidikan Pluralisme", Suara Pembaharuan, 23 September 2000.

Syamsi, Ibnu, "Potensi Konflik Sosial Masyarakat di Kelurahan Condong Catur Yogyakarta", Jurnal Fondasia, No. 9/Vol.I/Tahun VIII/ 2009.

Syamsudin, M., "The Burden of Indigenous People In Dealing with State Regulation", dalam Jurnal Hukum, Vol. 15 No. 3 tahun 2008.

Syatibi, As-, Al-Muwafaqat fi Ushul assyariah, Beirut: Dam al-Jill.

The Asian Moslem Action Network Indonesia, Dilema Kebebasan Beragama di Indonesia: Studi Kasus Pembakaran Rumah Ibadah di Sampang Madura, Tahun 2012.

Tualeka, Hamzah, "Konflik dan Integrasi Sosial bernuansa Agama (Studi tentang Pola Penyelesaian Konflik Ambon-Lease dalam Perspektif Masyarakat", Disertasi tidak 
dipublikasikan, Program Pasca sarjana IAIN Sunan Ampel

Surabaya, 2010.

Turner, Bryan S. Sosiologi Islam - Suatu Telaah Analitis Atas Tesa Sosiologi Weber (Terj. A.G. Ticoalu). Jakarta: Rjawali, 1984.

Wahid, Abdurrahman. Agama dan Kekerasan, Dari Anarkhisme Politik Ke Teologi Kekerasan. Jakarta: PPIPNU, 1998.

Weber, Max. Sosiologi Agama (Terj. Muhammad Yamin). Yogyakarta: IRCiSoD, 2002.

Williams, Howard, Filsafat Politik Kant, Penerjemah: Muhammad Hardani, Surabaya: JP-Press, 2003.

Wiyata, Latif, Carok: Konflik Kekerasan dan Harga Diri Orang Madura, Yogyakarta: LKiS, 2002.

Zamroni, Pengantar Pengembangan Teori Sosial, Yogyakarta: Tiara Wacana, 1992. 